Metallophysics and Advanced Technologies

Металофіз. новітні технол.

Metallofiz. Noveishie Tekhnol.

2019 , vol. 41 , No. 1 , pp. $13-25$

https://doi.org/10.15407/mfint.41.01.0013

Reprints available directly from the publisher
(C) 2019 G. V. Kurdyumov Institute for Metal Physics, National Academy of Sciences of Ukraine Published by license under the G. V. Kurdyumov Institute for Metal PhysicsN.A.S. of Ukraine Publishers imprint. Printed in Ukraine.

PACS numbers: 61.72.S-, 64.70.kd, 81.10.Aj, 81.10.Jt, 81.30.Bx, 81.30.Kf, 81.65.Lp

\title{
Analysis of the Stability of $\alpha \rightarrow \gamma$ Plane Front of Recrystallization in Ferritic Alloys During Carburization
}

\author{
O. V. Movchan and K. O. Chernoivanenko \\ National Metallurgical Academy of Ukraine, \\ 4 Gagarin Ave., \\ UA-49600 Dnipro, Ukraine
}

The $\alpha \rightarrow \gamma$ recrystallization of carbon-supersaturated ferrite alloyed with $\alpha$ stabilizer is analysed. The $\alpha$-stabilizer is redistributed between austenite and ferrite by recrystallization. A plane front of recrystallization becomes unstable and is transformed into cellular or dendrite one. The perturbation method, which is developed by W. W. Mullins and R. F. Sekerka for crystallizing alloys, is used in the analysis. A sinusoidal perturbation with infinitesimal amplitude is introduced into a plane front of recrystallization. The rate of movement of each element of the interphase surface is calculated by means of the diffusion flow of carbon from the austenite and by the flow of $\alpha$-stabilizer into the ferrite. The velocities are equated, and an expression for the change of perturbation amplitude is obtained. The most significant factors influencing on the stability of the $\alpha \rightarrow \gamma$ plane front of recrystallization are as follow: the difference in concentrations of $\alpha$-stabilizer in ferrite and austenite at the interface, the average velocity of front, the diffusion coefficient of the $\alpha$ stabilizer in ferrite, the coefficient of the interface tension. All factors depend on temperature. Therefore, the significance of factors can vary with temperature changes. The example of $\mathrm{Fe}-\mathrm{Si}-\mathrm{C}$ alloys shows the correspondence of the theoretical and experimental results of the study. The possibility of applying the obtained results to describing the $\alpha \rightarrow \gamma+$ carbide cooperative transformation in ferritic iron alloys with carbide-forming elements during carburizing is shown.

Key words: ferritic alloys, carburizing, $\alpha \rightarrow \gamma$ recrystallization front, cellular structure, perturbation method.

Corresponding author: Kateryna Oleksandrivna Chernoivanenko

E-mail: ekatmovchan@gmail.ua

Citation: O. V. Movchan and K. O. Chernoivanenko, Analysis of the Stability of $\alpha \rightarrow \gamma$ Plane Front of Recrystallization in Ferritic Alloys During Carburization, Metallofiz. Noveishie Tekhnol., 41, No. 1: 13-25 (2019), DOI: 10.15407/mfint.41.01.0013. 
Проаналізовано $\alpha \rightarrow \gamma$-перекристалізацію при пересиченні Карбоном фериту, легованого $\alpha$-стабілізатором. При перекристалізації $\alpha$-стабілізатор перерозподіляється між аустенітом і феритом, плаский фронт перекристалізації втрачає стійкість і трансформується в комірчастий або дендритний. При аналізі було використано методу збурень, яку було розроблено W. W. Mullins, R. F. Sekerka для стопів, що кристалізуються. На плаский фронт перекристалізації було накладено синусоїдальне збурення з нескінченно малою амплітудою. Швидкість переміщення кожного елементу міжфазної поверхні обчислювалася через дифузійний потік Карбону з аустеніту та через потік $\alpha$-стабілізатора у ферит. Швидкості було зрівняно й одержано вираз для зміни амплітуди збурення. Встановлено найзначущі чинники, що впливають на стійкість плаского фронту $\alpha \rightarrow \gamma$-перекристалізації, а саме: ріжниця концентрацій $\alpha$-стабілізатора у фериті й аустеніті на міжфазній межі, середня швидкість переміщення фронту, коефіцієнт дифузії $\alpha$-стабілізатора у фериті, коефіцієнт натягу міжфазної поверхні. Всі чинники залежать від температури; тому з її зміною значимість чинників може змінюватися. На прикладі стопів системи $\mathrm{Fe}-\mathrm{Si}-\mathrm{C}$ показано відповідність теоретичних та експериментальних результатів дослідження. Показано можливість застосування одержаних результатів для опису кооперативного перетворення $\alpha \rightarrow \gamma+$ карбід при навуглецьовуванні феритних стопів заліза з карбідоутворювальними елементами.

Ключові слова: феритні стопи, навуглецьовування, фронт $\alpha \rightarrow \gamma$-перекристалізації, коміркова структура, метода збурень.

Проанализирована $\alpha \rightarrow \gamma$-перекристаллизация при пересыщении углеродом феррита, легированного $\alpha$-стабилизатором. При перекристаллизации $\alpha$-стабилизатор перераспределяется между аустенитом и ферритом, плоский фронт перекристаллизации теряет устойчивость и трансформируется в ячеистый или дендритный. При анализе был использован метод возмущений, который был разработан W. W. Mullins, R. F. Sekerka для кристаллизующихся сплавов. На плоский фронт перекристаллизации было наложено синусоидальное возмущение с бесконечно малой амплитудой. Скорость перемещения каждого элемента межфазной поверхности вычислялась через диффузионный поток углерода из аустенита и через поток $\alpha$-стабилизатора в феррит. Скорости были приравнены и получено выражение для изменения амплитуды возмущения. Установлены наиболее значимые факторы, влияющие на устойчивость плоского фронта $\alpha \rightarrow \gamma$-перекристаллизации, а именно: разность концентраций $\alpha$-стабилизатора в феррите и аустените на межфазной границе, средняя скорость перемещения фронта, коэффициент диффузии $\alpha$-стабилизатора в феррите, коэффициент натяжения межфазной поверхности. Все факторы зависят от температуры; поэтому с её изменением значимость факторов может изменяться. На примере сплавов системы $\mathrm{Fe}-\mathrm{Si}-\mathrm{C}$ показано соответствие теоретических и экспериментальных результатов исследования. Показана возможность применения полученных результатов для описания кооперативного превращения $\alpha \rightarrow \gamma+$ карбид при науглероживании ферритных сплавов железа с карбидообразующими элементами.

Ключевые слова: ферритные сплавы, науглероживание, фронт $\alpha \rightarrow \gamma$ перекристаллизации, ячеистая структура, метод возмущений. 


\section{INTRODUCTION}

Various phase transformations can occur during carburization or decarburization in a gas atmosphere in iron alloys with $\alpha$-stabilizers, such as $\alpha \leftrightarrow \gamma$ recrystallization, release of special carbides, intermetallides, melting, and crystallization. The ferrite converts to austenite ( $\alpha \rightarrow \gamma$ recrystallization) by carburization at a temperature below $910^{\circ} \mathrm{C}$. In this case, ferrite and austenite are separated by a plane interfacial surface (Fig. 1, $a$ ). The transformation of alloyed ferrite with

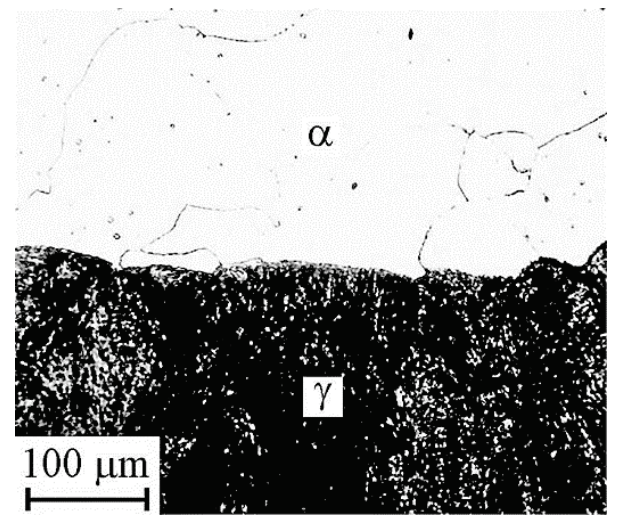

$a$

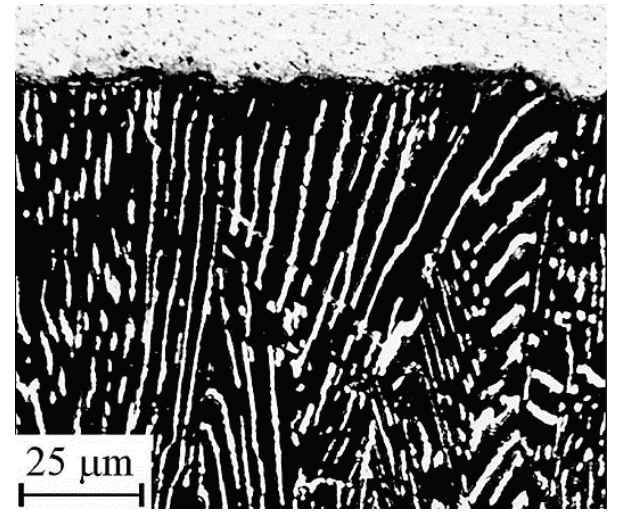

$c$
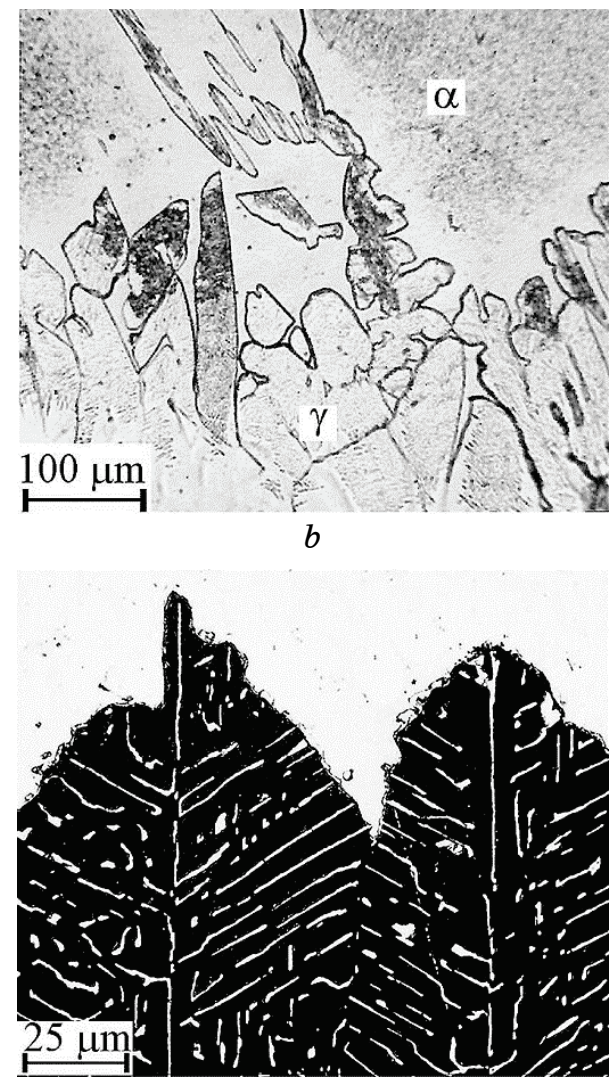

$d$

Fig. 1. Structure of the transformation front during carburization: $a-\mathrm{Fe} ; b-$ $\mathrm{Fe}-17 \% \mathrm{Cr} ; c, d-\mathrm{Fe}-24 \% \mathrm{Cr}$. Carburizing temperature: $a-850^{\circ} \mathrm{C} ; b-$ $1050^{\circ} \mathrm{C} ; \mathrm{c}, d-1200^{\circ} \mathrm{C}$. Carburizing time: $a, b-1$ hour, $c-0.5$ hours, $d-2$ hours. 
the $\alpha$-stabilizer ( $\mathrm{Me}$ ) is accompanied by redistribution of ferritestabilizing component between the phases and the loss of stability of the plane front (Fig. 1, $b$ ).

If two or more phase transformations occur simultaneously, multiphase reactions are possible [1]. For example, a natural $\gamma-\mathrm{M}_{6} \mathrm{C}$ composite can be formed during carburization in ferritic iron alloys alloyed by the type of high-speed steels. This represents austenite reinforced with special carbide fibres. The fibres are direct perpendicularly to the carburized surface. The composite has high indexes of the hardness, heat resistance and wear resistance. However, if the alloy has a component that does not directly participate in the formation of the composite structure, then such structural transformations as transformation of the plane transformation front into a cellular one and then into a cellular-dendritic one are possible. In this case, carbide fibres lose onepointedness, which leads to reduced wear resistance (Fig. 1, $c, d$ ). This explains the interest in the reasons for the loss of stability of the plane transformation front during the reaction diffusion of carbon into alloyed ferrite.

The transformation of the $\alpha \rightarrow \gamma$ plane front of recrystallization into cellular and then to cellular-dendritic ones has been studied by the authors [2-5]. In these studies, the instability of a plane front was due to the supersaturation of ferrite by carbon at some distance from the front. The equilibrium carbon concentration in ferrite $\left({ }^{p} X_{C}^{\alpha / \gamma}\right)$ corresponding to $\alpha \rightarrow \gamma$ recrystallization varies with the concentration of the $\alpha$-stabilizer ${ }^{p} X_{\mathrm{Me}}^{\alpha / \gamma}$ along the ab line on the diagram (Fig. 2). The super-

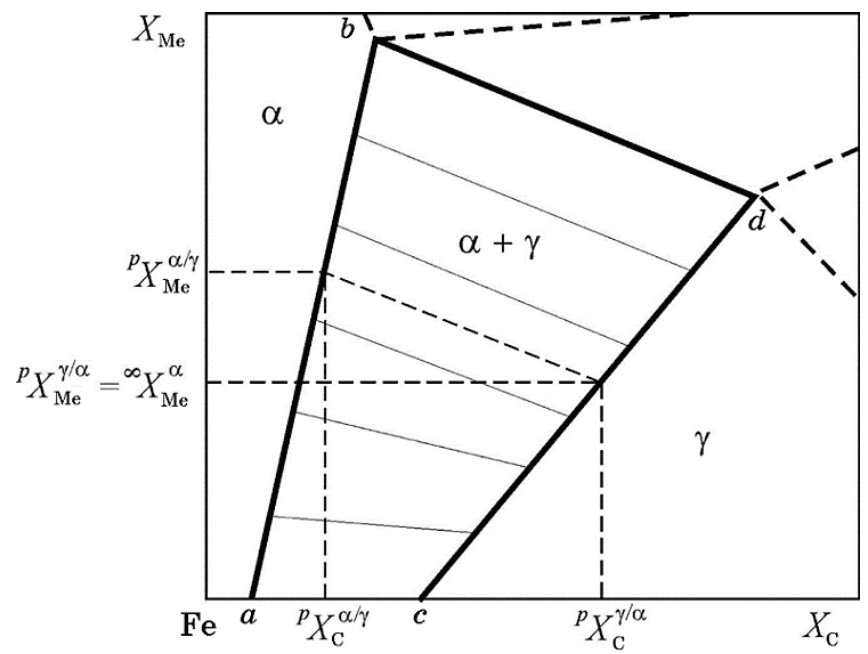

Fig. 2. Schematic cross-section of the isothermal phase diagram of the $\mathrm{Fe}-\mathrm{C} \alpha$ stabilizer for the temperature below $\alpha \leftrightarrow \gamma$ polymorphic transformation of the pure iron. 
saturation was explained by the different diffusion mobility of Me and carbon (C) in ferrite and, correspondingly, by a higher gradient of the equilibrium concentration of carbon in comparison with the true one. The described effect was called concentration supersaturation by analogy with the concentration supercooling during crystallization of alloys [6]. However, this approach meets objections. Usually, the loss of stability of a plane front is observed when the concentration of carbon in the ferrite is equal to the maximum solubility.

The concentration of the $\alpha$-stabilizer in the ferrite increases and, when the steady-state process is reached, it becomes equal ${ }^{p} X_{\mathrm{Me}}^{\alpha / \gamma}$ by recrystallization. The concentration of carbon also increases. Nevertheless, for forming a zone supersaturated with carbon before the front, its diffusion is required in the direction of increasing of the chemical potential, which is impossible. Consequently, the concept of 'concentration supersaturation' in this case is not applicable. Thus, the loss of stability of the $\alpha \rightarrow \gamma$ plane front of recrystallization is a diffusion problem.

Objective of this paper is a study of the $\alpha \rightarrow \gamma$ front recrystallization stability in carburized ferritic iron alloys.

\section{THEORETICAL METHODOLOGY}

The velocity of advance of the $\alpha \leftrightarrow \gamma$ recrystallization front is determined by the diffusion flux of carbon that supplied to the interfacial surface or removed from it. Diffusion processes in the solid phase depend little on time. So, the investigated phase transition (because of reactive diffusion) can be regarded as series of successive quasistationary states. The velocity of advance of the front $v_{a v}$ and the concentration profiles of the components are assumed constant in each of them. The concentrations (molar fractions) of the component $k$ in the phase $f_{1}$ at the boundary with the phase $f_{2} X_{k}^{f 1 / f 2}$ correspond to thermodynamic equilibrium. The concentration of the $\alpha$-stabilizer in the growing phase is equal to its concentration in the initial alloy $\left(X_{k}^{f 2 / f 1}={ }^{0} X_{k}^{f 1}\right)$.

Assuming thermodynamic equilibrium on the interphase boundary, there should be a jump in the concentrations of the alloy components on the boundary between ferrite and austenite. Its value can be determined by the isothermal section of the $\mathrm{Fe}-\mathrm{Me}-\mathrm{C}$ phase diagram at the carburization temperature (Fig. 2).

The concentrations of the components $\mathrm{Me}$ and $\mathrm{C}(k)$ in ferrite on a plane boundary with austenite ${ }^{p} X_{k}^{\alpha / \gamma}$ and in austenite with ferrite ${ }^{p} X_{k}^{\gamma / \alpha}$ are related by means of the expression:

$$
\left({ }^{p} X_{k}^{\alpha / \gamma}-{ }^{\min } X_{k}^{\alpha / \gamma}\right) /\left({ }^{\max } X_{k}^{\alpha / \gamma}-{ }^{\min } X_{k}^{\alpha / \gamma}\right)=
$$




$$
=\left({ }^{p} X_{k}^{\gamma / \alpha}-{ }^{\min } X_{k}^{\gamma / \alpha}\right) /\left({ }^{\max } X_{k}^{\gamma / \alpha}-{ }^{\min } X_{k}^{\gamma / \alpha}\right),
$$

where ${ }^{\min } X_{k}^{\alpha / \gamma},{ }^{\max } X_{k}^{\alpha / \gamma},{ }^{\min } X_{k}^{\gamma / \alpha},{ }^{\max } X_{k}^{\gamma / \alpha}$ are the minimum and maximum component concentrations at the interface (in Fig. 2, points $a, b$, $c, d$, respectively).

The perturbation method proposed by W. W. Mullins and R.F. Sekerka [7] for the crystallization of alloys was used for determining the criterion for the stability of the $\alpha \rightarrow \gamma$ plane front of recrystallization. The method consists in applying a sinusoidal perturbation with infinitesimal amplitude $\varphi(x, \tau)=\chi(\tau) \sin \omega x$ to a plane front of recrystallization. If the perturbation amplitude increases at some frequency $\omega$, the plane crystallization front is considered unstable.

\subsection{Basic Equations}

The problem was considered in a coordinate system with a beginning on a moving interface. The $x$-axis is directed along the front of the recrystallization, $z$-axis is perpendicular. The advance of the front is due to the supply of carbon from the austenite to it and the removal of the $\alpha$ stabilizer into ferrite. It is required to solve the following differential equations to determine responsible for fluxes of the concentration fields $\mathrm{C}$ in the austenite and $\mathrm{Me}$ in the ferrite at the disturbed interface:

$$
\begin{gathered}
\frac{\partial^{2} X_{\mathrm{C}}^{\gamma}}{\partial x^{2}}+\frac{\partial^{2} X_{\mathrm{C}}^{\gamma}}{\partial z^{2}}+\frac{v_{a v}}{D_{\mathrm{C}}^{\gamma}} \frac{\partial X_{\mathrm{C}}^{\gamma}}{\partial z}=0, \\
\frac{\partial^{2} X_{\mathrm{Me}}^{\alpha}}{\partial x^{2}}+\frac{\partial^{2} X_{\mathrm{Me}}^{\alpha}}{\partial z^{2}}+\frac{v_{a v}}{D_{\mathrm{Me}}^{\alpha}} \frac{\partial X_{\mathrm{Me}}^{\alpha}}{\partial z}=0,
\end{gathered}
$$

where $v_{a v}$ is the velocity of displacement of the front of recrystallization averaged over the wavelength of the perturbation; $D_{\mathrm{C}}^{\gamma}$ is the coefficient of carbon diffusion in austenite; $D_{\mathrm{Me}}^{\alpha}$ is coefficient of diffusion of the $\alpha$ stabilizer in ferrite; $X_{\mathrm{C}}^{\gamma}$ is equilibrium carbon concentration in austenite; $X_{\mathrm{Me}}^{\alpha}$ is equilibrium concentration of the $\alpha$-stabilizer in ferrite.

The boundary conditions of the problem are formulated below.

\subsection{Boundary Conditions}

The concentrations of components at the interphase boundary can be represented as follow:

$$
\begin{aligned}
& X_{\mathrm{C}}^{\gamma / \alpha}={ }^{p} X_{\mathrm{C}}^{\gamma / \alpha}+a \chi \sin \omega x, \\
& X_{\mathrm{Me}}^{\alpha / \gamma}={ }^{p} X_{\mathrm{Me}}^{\alpha / \gamma}+b \chi \sin \omega x,
\end{aligned}
$$


where, according to (1), ${ }^{p} X_{\mathrm{C}}^{\gamma / \alpha}={ }^{\min } X_{\mathrm{C}}^{\gamma / \alpha}+K\left({ }^{\max } X_{\mathrm{C}}^{\gamma / \alpha}-{ }^{\min } X_{\mathrm{C}}^{\gamma / \alpha}\right)$, ${ }^{p} X_{\mathrm{Me}}^{\alpha / \gamma}={ }^{\min } X_{\mathrm{Me}}^{\alpha / \gamma}+K\left({ }^{\max } X_{\mathrm{Me}}^{\alpha / \gamma}-{ }^{\min } X_{\mathrm{Me}}^{\alpha / \gamma}\right)$, and $K=\frac{{ }^{\infty} X_{\mathrm{Me}}^{\alpha}-{ }^{\min } X_{\mathrm{Me}}^{\gamma / \alpha}}{{ }^{\max } X_{\mathrm{Me}}^{\gamma / \alpha}-{ }^{\min } X_{\mathrm{Me}}^{\gamma / \alpha}}$.

The coefficients $a$ and $b$ will be determined in the course of the solution.

There is a periodically varying Laplace pressure in each of the coexisting phases when a sinusoidal perturbation is imposed on the interface:

$$
P^{f}=\sigma\left(1 / r_{1}+1 / r_{2}\right),
$$

where $\sigma$ is the coefficient of surface tension; $r_{1}$ and $r_{2}$ are the main radii of curvature of the interface.

The equilibrium concentrations of the components are changed at the interphase boundary.

According to Hillert [8], these changes can be determined by constructing a common tangent plane to the surfaces of the thermodynamic potentials $G^{\alpha}$ and $G^{\gamma}$. As a result, we obtain the relation:

$$
\frac{P^{\gamma} V^{\gamma}}{R T}=h\left(X_{\mathrm{C}}^{\gamma / \alpha}-{ }^{p} X_{\mathrm{C}}^{\gamma / \alpha}\right)+q\left(X_{\mathrm{Me}}^{\alpha / \gamma}-{ }^{p} X_{\mathrm{Me}}^{\alpha / \gamma}\right) .
$$

Here, $P^{\gamma}=\sigma \omega^{2} \chi \sin \omega x$ is the capillary pressure in austenite, $V^{\gamma}$ is the austenite volume, $T$ is temperature, $R$ is the gas constant, and $h=\left.\left({ }^{p} X_{\mathrm{C}}^{\gamma / \alpha}-{ }^{p} X_{\mathrm{C}}^{\alpha / \gamma}\right) \frac{\partial^{2} G^{\gamma}}{\partial X_{\mathrm{C}}^{2}}\right|_{X_{\mathrm{C}}={ }^{p} X_{\mathrm{C}}^{\gamma / \alpha}}, q=\left.\left({ }^{p} X_{\mathrm{Me}}^{\gamma / \alpha}-{ }^{p} X_{\mathrm{Me}}^{\alpha / \gamma}\right) \frac{\partial^{2} G^{\alpha}}{\partial X_{\mathrm{Me}}^{2}}\right|_{X_{\mathrm{Me}}={ }^{p} X_{\mathrm{Me}}^{\alpha / \gamma}}$.

Taking into account (4) and (5), we obtain:

$$
a=\frac{\sigma \omega^{2} V_{m}^{\gamma}}{h R T}-\frac{q}{h} b,
$$

where $V_{m}^{\gamma}$ is the molar volume of austenite.

\subsection{The Investigation of the Basic Equations}

The formulation of Eqs. (2) and (3) corresponding to conditions (4) and (5) on the interphase surface has the form:

$$
\begin{aligned}
& X_{\mathrm{C}}^{\gamma}(x, z)={ }^{\min } X_{\mathrm{C}}^{\gamma / \alpha}+K\left({ }^{\max } X_{\mathrm{C}}^{\gamma / \alpha}-{ }^{\min } X_{\mathrm{C}}^{\gamma / \alpha}\right) \exp \left(-\frac{v_{a v}}{D_{\mathrm{C}}^{\gamma}} z\right)+ \\
& +\chi\left[a+K\left({ }^{\max } X_{\mathrm{C}}^{\gamma / \alpha}-{ }^{\min } X_{\mathrm{C}}^{\gamma / \alpha}\right) \frac{v_{a v}}{D_{\mathrm{C}}^{\gamma}}\right] \sin (\omega x) \exp \left(-\omega_{\mathrm{C}} z\right),
\end{aligned}
$$




$$
\begin{aligned}
& X_{\mathrm{Me}}^{\alpha}(x, z)={ }^{\infty} X_{\mathrm{Me}}^{\alpha}+\Delta^{p} X_{\mathrm{Me}}^{\alpha-\gamma} \exp \left(-\frac{v_{a v}}{D_{\mathrm{Me}}^{\alpha}} z\right)+ \\
& +\chi\left[b+\Delta^{p} X_{\mathrm{Me}}^{\alpha-\gamma} \frac{v_{a v}}{D_{\mathrm{Me}}^{\alpha}}\right] \sin (\omega x) \exp \left(-\omega_{\mathrm{Me}} z\right),
\end{aligned}
$$

where

$$
\begin{gathered}
\Delta^{p} X_{\mathrm{Me}}^{\alpha-\gamma}={ }^{\min } X_{\mathrm{Me}}^{\alpha / \gamma}-{ }^{\min } X_{\mathrm{Me}}^{\gamma / \alpha}+K\left({ }^{\max } X_{\mathrm{Me}}^{\alpha / \gamma}-{ }^{\min } X_{\mathrm{Me}}^{\alpha / \gamma}-{ }^{\max } X_{\mathrm{Me}}^{\gamma / \alpha}+{ }^{\min } X_{\mathrm{Me}}^{\gamma / \alpha}\right), \\
\omega_{\mathrm{C}}=\frac{v_{a v}}{2 D_{\mathrm{C}}^{\gamma}}+\sqrt{\left(\frac{v_{a v}}{2 D_{\mathrm{C}}^{\gamma}}\right)^{2}+\omega^{2}, \omega_{\mathrm{Me}}}=\frac{v_{a v}}{2 D_{\mathrm{Me}}^{\alpha}}+\sqrt{\left(\frac{v_{a v}}{2 D_{\mathrm{Me}}^{\alpha}}\right)^{2}+\omega^{2}} .
\end{gathered}
$$
low:

The gradients of concentrations on the interphase surface are as fol-

$$
\begin{aligned}
& \left(\frac{\partial X_{C}^{\gamma}}{\partial z}\right)_{z=\varphi}=\left\{K\left({ }^{\max } X_{\mathrm{C}}^{\gamma / \alpha}-{ }^{\min } X_{\mathrm{C}}^{\gamma / \alpha}\right)\left(\frac{v_{a v}}{D_{\mathrm{C}}^{\gamma}}\right)^{2}-\right. \\
& \left.-\omega_{\mathrm{C}}\left[a+K\left({ }^{\max } X_{\mathrm{C}}^{\gamma / \alpha}-{ }^{\min } X_{\mathrm{C}}^{\gamma / \alpha}\right) \frac{v_{a v}}{D_{\mathrm{C}}^{\gamma}}\right]\right\} \chi \sin (\omega x)- \\
& -K\left({ }^{\max } X_{\mathrm{C}}^{\gamma / \alpha}-{ }^{\min } X_{\mathrm{C}}^{\gamma / \alpha}\right) \frac{v_{a v}}{D_{\mathrm{C}}^{\gamma}} \\
& \left(\frac{\partial X_{\mathrm{Me}}^{\alpha}}{\partial z}\right)_{z=\varphi}=\left\{\Delta^{p} X_{\mathrm{Me}}^{\alpha-\gamma}\left(\frac{v_{a v}}{D_{\mathrm{Me}}^{\alpha}}\right)^{2}-\omega_{\mathrm{Me}}\left[b+\Delta^{p} X_{\mathrm{Me}}^{\alpha-\gamma} \frac{v_{a v}}{D_{\mathrm{Me}}^{\alpha}}\right]\right\} \sin (\omega x)- \\
& -\Delta^{p} X_{\mathrm{Me}}^{\alpha-\gamma} \frac{v_{a v}}{D_{\mathrm{Me}}^{\alpha}} .
\end{aligned}
$$

(Terms above the first order in $\chi$ are not taken into account.)

The equality condition of the velocities of the displacement of each surface element calculated through the $\mathrm{C}$ inflow from the austenite and through the outflow of Me to the ferrite is introduced in the formulation of equations (2) and (3) to calculate the coefficients $a$ and $b$ :

$$
v(x)=-\frac{D_{\mathrm{C}}^{\gamma}}{X_{\mathrm{C}}^{\gamma / \alpha}-X_{\mathrm{C}}^{\alpha / \gamma}}\left(\frac{\partial X_{\mathrm{C}}^{\gamma}}{\partial z}\right)_{z=\varphi}=-\frac{D_{\mathrm{Me}}^{\alpha}}{X_{\mathrm{Me}}^{\alpha / \gamma}-X_{\mathrm{Me}}^{\gamma / \alpha}}\left(\frac{\partial X_{\mathrm{Me}}^{\alpha}}{\partial z}\right)_{z=\varphi} .
$$

The change in the concentrations of the components in ferrite and austenite under the influence of the Laplace pressure of one sign is approximately equal in value. Therefore, we accept: 


$$
\begin{gathered}
X_{\mathrm{C}}^{\gamma / \alpha}-X_{\mathrm{C}}^{\alpha / \gamma} \approx \Delta^{p} X_{\mathrm{C}}^{\gamma-\alpha}= \\
={ }^{\min } X_{\mathrm{C}}^{\gamma / \alpha}-{ }^{\min } X_{\mathrm{C}}^{\alpha / \gamma}+K\left({ }^{\max } X_{\mathrm{C}}^{\gamma / \alpha}-{ }^{\min } X_{\mathrm{C}}^{\gamma / \alpha}-{ }^{\max } X_{\mathrm{C}}^{\alpha / \gamma}+{ }^{\min } X_{\mathrm{C}}^{\alpha / \gamma}\right), \\
X_{\mathrm{Me}}^{\alpha / \gamma}-X_{\mathrm{Me}}^{\gamma / \alpha} \approx \Delta^{p} X_{\mathrm{Me}}^{\alpha-\gamma}, \\
b=\Delta{ }^{p} X_{\mathrm{Me}}^{\alpha-\gamma}\left\{K\left({ }^{\max } X_{\mathrm{C}}^{\gamma / \alpha}-{ }^{\min } X_{\mathrm{C}}^{\gamma / \alpha}\right)\left[\frac{v_{a v}^{2}}{D_{\mathrm{C}}^{\gamma}}-\omega_{\mathrm{C}} v_{a v}\right]-\omega_{\mathrm{C}} \frac{D_{\mathrm{C}}^{\gamma} \omega^{2} \sigma V_{m}^{\gamma}}{h R T}-\right. \\
\left.-\Delta^{p} X_{\mathrm{C}}^{\gamma-\alpha}\left(\frac{v_{a v}^{2}}{D_{\mathrm{Me}}^{\alpha}}-\omega_{\mathrm{C}} v_{a v}\right)\right\}\left(-D_{\mathrm{C}}^{\gamma} \omega_{\mathrm{C}} \Delta^{p} X_{\mathrm{Me}}^{\alpha-\gamma} \frac{q}{h}-D_{\mathrm{Me}}^{\alpha} \omega_{\mathrm{Me}} \Delta^{p} X_{\mathrm{C}}^{\gamma-\alpha}\right)^{-1} .
\end{gathered}
$$

Using data of Ref. [7], we obtain the following expression for the given rate of change of the perturbation amplitude:

$$
\frac{\chi^{\prime}}{\chi}=-\frac{D_{\mathrm{Me}}^{\alpha}}{\Delta^{p} X_{\mathrm{Me}}^{\alpha-\gamma}}\left\{\Delta^{p} X_{\mathrm{Me}}^{\alpha-\gamma}\left[\left(\frac{v_{a v}}{D_{\mathrm{Me}}^{\alpha}}\right)^{2}-\frac{\omega_{\mathrm{Me}} v_{a v}}{D_{\mathrm{Me}}^{\alpha}}\right]-\omega_{\mathrm{Me}} b\right\},
$$

where $\chi^{\prime}=\frac{d \chi}{d \tau}$.

The growth or damping of the perturbation $\chi$ depends on the sign of expression (14).

\section{DISCUSSION OF THE RESULTS}

The growth or damping of the perturbation depends on the sign of the expression in square brackets. The first term of this expression contains the parameters that responsible for the diffusion redistribution of Me in the ferrite ahead of the recrystallization front. Its sign is always positive. The dependence on $\omega$ is close to linear.

The difference in the concentrations of Me between ferrite and austenite on a planar interfacial surface ${ }^{p} X_{\mathrm{Me}}^{\alpha / \gamma}-{ }^{\infty} X_{\mathrm{Me}}^{\alpha}$ depends on the initial concentration $\mathrm{Me}$ in the alloy and the coordinates of the node points $a, b, c, d$ on the diagram (Eq. (1), Fig. 2). The second term characterizes the counteraction of surface tension to the curvature of the front of recrystallization. Its frequency dependence is close to cubic. Thus, the surface factor is more significant in the case of short-wave perturbations, while the diffusion factor is more significant for longwavelength perturbations. The total dependence is extreme.

The alloys of the $\mathrm{Fe}-\mathrm{Si}-\mathrm{C}$ system were chosen for the experimental comparison with the theoretical results. The structure of diffusion layers was considered in [2-4]. While $\alpha \rightarrow \gamma$ recrystallization is not complicated by the presence of other phases, except for austenite and 
ferrite, the following values of the parameters required to obtain the numerical value of Eq. (14) were accepted: ${ }^{0} D_{\mathrm{Si}}^{\alpha}=4.4 \cdot 10^{-5} \mathrm{~m}^{2} / \mathrm{s}, Q_{\mathrm{Si}}^{\alpha}=$ $=2.02 \cdot 10^{5} \mathrm{~J} / \mathrm{mol},{ }^{0} D_{\mathrm{C}}^{\gamma}=7 \cdot 10^{-5} \mathrm{~m}^{2} / \mathrm{s}, Q_{\mathrm{C}}^{\gamma}=1.59 \cdot 10^{5} \mathrm{~J} / \mathrm{mol}[9]$, the concentration coordinates of the points $a, b, c, d$ were found in [10]. The velocity of the advancing front of recrystallization $v_{a v}$ averaged along the wavelength of the perturbation was determined experimentally using the following dependence of the width of the growing phase on time: $L=$ const $\cdot \tau^{1 / 2}$, whence $v_{a v}=L / 2 \tau$.

The microstructure of the front of recrystallization of carburized $\mathrm{Fe}-\mathrm{Si}$ alloys is shown on Fig. 3. An increase in the mole fraction of $\mathrm{Si}$ in the initial ferrite to $\mathbf{0 . 0 2 7}$ leads to a loss of stability of the plane front of recrystallization and the formation of a cellular structure.

The calculations using (14) showed the following. The rate of movement of the plane front of recrystallization is significantly affected to its stability considering constant values of temperature-dependent factors such as the coordinates of the node points on the state diagram, the diffusion coefficient, the surface tension coefficient. The rate of movement of the front decreases with time according to a parabolic law.

According to (14), the recrystallization front becomes unstable at ${ }^{\infty} X_{\mathrm{Si}}^{\alpha}=0.027$ after the rate of its progress has slowed down to $v_{a v}=$ $=0.215 \mathrm{~mm} / \mathrm{h}$ (Fig. 4). According to the determination of the Stefan problem, the rate of advance of the recrystallization front decreases with time in accordance with the expression $v_{a v}=\operatorname{const} \cdot \tau^{-1 / 2}$. Thus, the obtained results allow determining the distance (on which the front loses stability) from the saturating surface.

The stability of the plane front $\alpha \rightarrow \gamma$ of recrystallization depends on several factors. The most significant of which are the difference in the

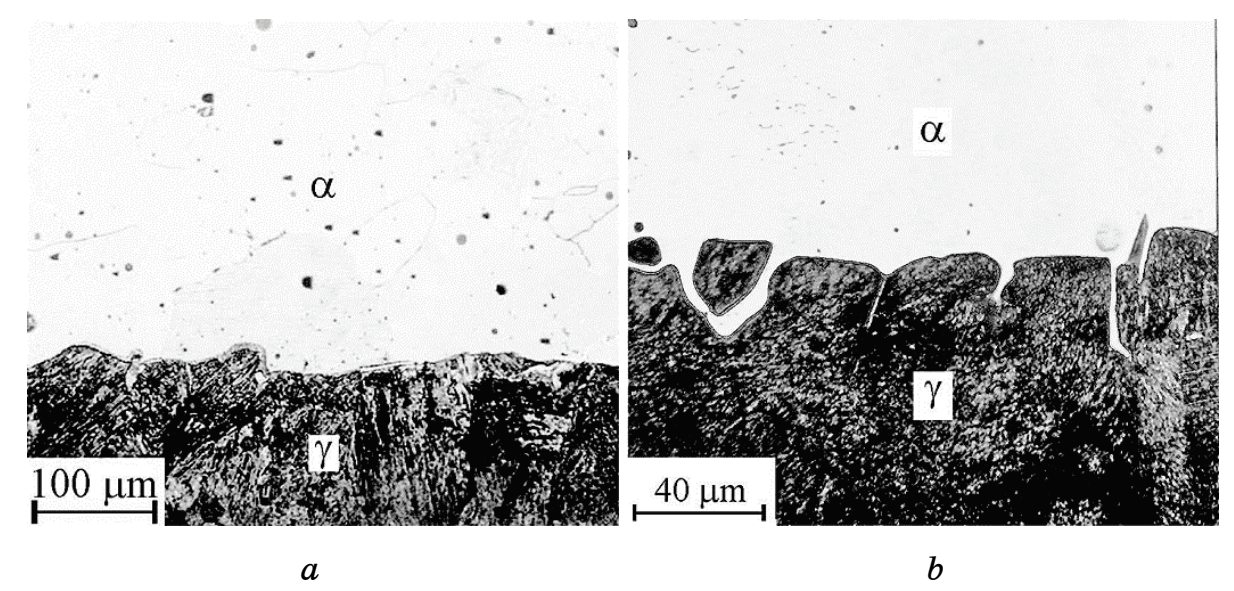

Fig. 3. Microstructure of the carburized alloy $\mathrm{Fe}-\mathrm{Si}: a-{ }^{\infty} X_{\mathrm{Si}}^{\alpha}=0.016, b-$ ${ }^{\infty} X_{\mathrm{Si}}^{\alpha}=0.027 . T=850^{\circ} \mathrm{C}$; time 1 hour. 
concentrations of Me between ferrite and austenite at the interface, the average velocity of front, the diffusion coefficient of Me in the ferrite, and the coefficient of the interfacial surface tension.

Each of factors depends on the carburization temperature according to different laws. Therefore, their ranking by significance may vary with a change in temperature. It is possible to estimate which of the factors most significantly affects to the structure of the carburized layer under given processing conditions.

\section{RESEARCH OF THE $\alpha \rightarrow \gamma+$ CARBIDE TRANSFORMATION}

As already mentioned, the formation of austenite and carbide is possible at the same time during the carburization of ferritic iron alloys with carbide-forming elements. The reaction $\alpha \rightarrow \gamma+$ carbide is realized in the case when the composition of the carburized $\mathrm{Fe}-\mathrm{Me}$ alloy passes the ferrite vertex of the conodal triangle $\alpha+\gamma+$ carbide on the isothermal section of the $\mathrm{Fe}-\mathrm{Me}-\mathrm{C}$ phase diagram. The concentration gradient of Me appears in a supersaturated ferrite between austenite and carbide. The gradient ensures its redistribution between these phases during their growth with a constant inflow of carbon. Austenite and carbide grow cooperatively forming colonies like eutectoid (representing a natural composite [1]). The concentration of Me in the colonies is equal to the concentration in the initial ferrite over the entire depth of the carburized layer.

The alloy can be additionally alloyed with a $\mathrm{Me}_{2}$ component in order

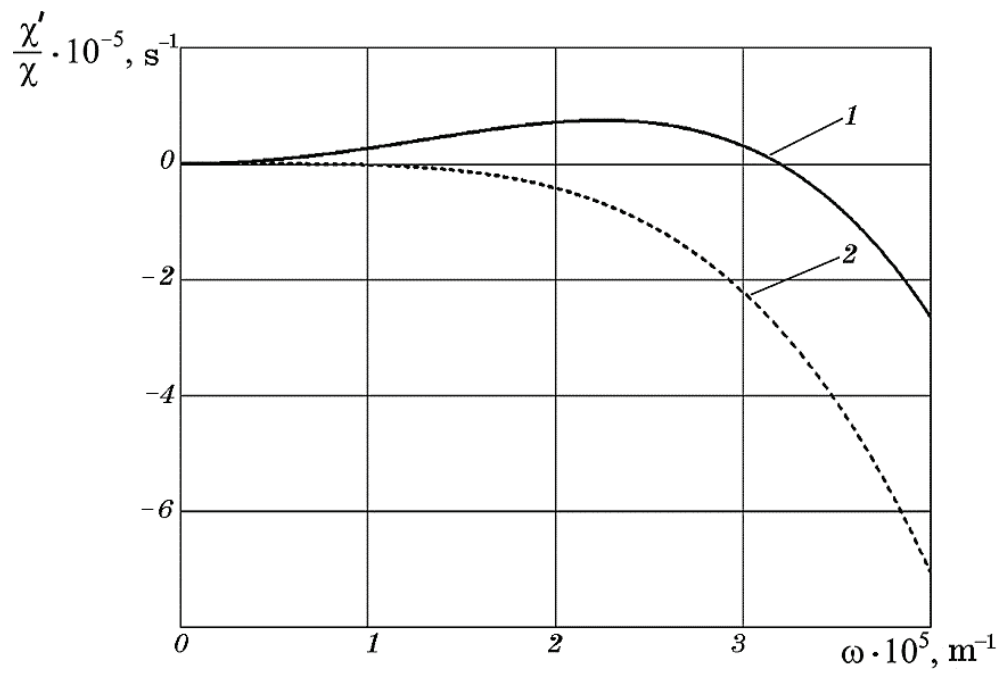

Fig. 4. Calculated frequency dependence of the rate of change of the perturbation amplitude; $1-v_{a v}=0.215 \mathrm{~mm} / \mathrm{h}, 2-v_{a v}=0.220 \mathrm{~mm} / \mathrm{h}$. 
to change the properties of the composite matrix, for example, heat resistance or corrosion resistance. If $\mathrm{Me}_{2}$ does not form isomorphous carbides with $\mathrm{Me}$ and it is slightly soluble in carbide reinforcing the composite, $\mathrm{Me}_{2}$ will be redistribute between the growing phases and initial ferrite. This process is similar to $\alpha \rightarrow \gamma$ recrystallization. This process is much more complicated that requiring studying the redistribution of $\mathrm{Me}_{2}$ between three phases. It is the subject of investigation. However, the presented model can be used as a basic model.

\section{CONCLUSIONS}

The investigations of the stability of the transformation front during $\alpha \rightarrow \gamma$ single-phase recrystallization in carburized ferritic alloys of iron are carried out in this work.

The perturbation method (W. W. Mullins, R. F. Sekerka) was chosen to determine the criterion for the stability of the $\alpha \rightarrow \gamma$ plane front of recrystallization. It consists in depositing a sinusoidal perturbation with infinitesimal amplitude onto the plane front of recrystallization during the crystallization of alloys.

In this paper, we obtained results that allow us to determine the distance from the saturating surface on which the recrystallization front $\alpha \rightarrow \gamma$ loses stability. We identified several factors that influence on the stability of the plane front. The most significant of which are the difference in the concentrations of the $\alpha$-stabilizer between ferrite and austenite at the interface, the average velocity of front displacement, the diffusion coefficient of the $\alpha$-stabilizer in ferrite, and the coefficient of tension of the interfacial surface. The results reported in this paper permit us to estimate the most significant factors, which affect the structure of the carburized layer under given processing conditions.

The data received give opportunities to study the cooperative transformation ( $\alpha \rightarrow \gamma+$ carbide) during carburization.

\section{REFERENCES}

1. A. V. Movchan and A. P. Bachurin, and L. G. Pedan, Dopov. Nac. Akad. Nauk Ukr., No. 7: 104 (2000) (in Russian).

2. K. P. Bunin, V. I. Movchan, and V. V. Nikiforova, Izv. VUZov. Chern. Metall., No. 2: 106 (1977) (in Russian).

3. V. I. Movchan and V. V. Vladimirova, Izv. Akad. Nauk SSSR. Metally, No. 4: 91 (1982) (in Russian).

4. V. I. Movchan, V. V. Vladimirova, Izv. Akad. Nauk SSSR. Metally, No. 6: 52 (1988) (in Russian).

5. M. Ichinose, F. Togashi, K. Ishida, and T. Nishizawa, Metall. Mater. Trans., 25A, No. 3: 531 (1994).

6. B. Chalmers, Teoriya Zatverdevaniya (Principles of Solidification) (Moscow: 
Metallurgiya: 1968) (Russian translation).

7. W. W. Mullins and R. F. Sekerka, J.Appl. Phys., 35, No. 2: 444 (1964).

8. M. Hillert, Phase Equilibria, Phase Diagrams and Phase Transformations (Cambridge: Cambridge University Press: 2007).

9. M. A. Krishtal, Mekhanizm Diffuzii v Zheleznykh Splavakh [Diffusion Mechanism in Iron Alloys] (Moscow: Metallurgiya:1972) (in Russian).

10. V. Raghavan, J.Alloy Phase Diagrams. India, 2, No. 2: 97 (1986). 